\title{
The Cardiovascular Health Burdens of Solitary Confinement
}

\author{
Brie A. Williams, MD, MS $S^{1,2,3}$, Amanda Li, BA ${ }^{4,5}$, Cyrus Ahalt, MPP ${ }^{1,2}$, \\ Pamela Coxson, $P h D^{6,7}$, James G. Kahn, $M D, M P H^{8}$, and Kirsten Bibbins-Domingo, PhD, \\ $M D, M A S^{6,7,9,10}$
}

'Department of Medicine, Division of Geriatrics, University of California, San Francisco, San Francisco, USA; ${ }^{2}$ JUSTInnovate at UCSF, San Francisco, USA; ${ }^{3}$ Tideswell at UCSF, San Francisco, USA; ${ }^{4}$ School of Medicine, University of California, San Francisco, San Francisco, USA; ${ }^{5}$ Medical Student Training in Aging Research (MSTAR) Program, University of California Los Angeles, Los Angeles, USA; 'bepartment of Epidemiology \& Biostatistics, University of California, San Francisco, San Francisco, USA; ${ }^{7}$ Center for Vulnerable Populations at Zuckerberg San Francisco General Hospital, San Francisco, USA; ${ }^{8}$ Department of Institute for Health Policy Studies, University of California, San Francisco, San Francisco, USA; ${ }^{9}$ Population Health and Health Equity in the UCSF School of Medicine, San Francisco, USA; ${ }^{10}$ Clinical and Translational Science Training Institute, San Francisco, USA.

J Gen Intern Med 34(10): 1977-80

DOI: $10.1007 / \mathrm{s} 11606-019-05103-6$

(c) Society of General Internal Medicine 2019

\section{INTRODUCTION}

The American Medical Association recently called for the elimination of solitary confinement for the mentally ill, citing its mental health harms. ${ }^{1}$ In solitary confinement, people are held in a prison cell roughly the size of a parking space for $~$ 22-23 h per day with 1 or $2 \mathrm{~h}$ of exercise, also in isolation. ${ }^{2}$ Although the living conditions in these units (e.g., limited exercise, extreme loneliness) are known risk factors for adverse physical health outcomes including cardiovascular disease, ${ }^{2}$ the lifetime cardiovascular burden of solitary confinement is unknown.

\section{METHODS}

To estimate the lifetime cardiovascular disease burden and costs associated with solitary confinement, we used public data from a 2015 lawsuit $^{3}$ describing the prevalence of hypertension diagnoses among two groups of incarcerated men ages 27-45: those housed in one prison's solitary confinement "supermax" units and those in the prison's less-isolating maximum security units (Table 1). Those in solitary confinement received no group recreation or contact visits and few (if any) phone calls; those in maximum security received $2 \mathrm{~h}$ of daily group recreation, contact visits, and more calls. Individuals in solitary confinement scored an average of 54.9 on the UCLA Loneliness Scale (scale ranges $20-80,80$ is most lonely); those in maximum security averaged $41.6{ }^{3}$

Using the Cardiovascular Disease Policy Model, a computer simulation of cardiovascular disease in US adults, ${ }^{4}$ we estimated the lifetime incremental burden of disease, loss of quality-adjusted life years (QALYs), and medical costs associated with new diagnoses of hypertension at age 35 . We assumed average systolic blood pressure distributions and control rates among hypertensive 35-year-olds based on the

Published online June 21, 2019
2011-2014 National Health and Nutrition Examination Survey. Quality-of-life weights were based on observational data from the Global Burden of Disease study. Medical costs were estimated using California's Office of Statewide Health Planning and Development, deflated using cost-to-charge ratios and the ratio of the US national average costs to California's, and then inflated to 2017 dollars using the Consumer Price Index.

\section{RESULTS}

Over a lifetime, 1000 men with newly diagnosed hypertension at age 35 are expected to experience 10 additional myocardial infarctions and 21 additional cardiovascular accidents, representing a loss of 732 QALYs and over \$20 million in additional healthcare costs. Because individuals in solitary confinement experienced an absolute $31 \%$ higher hypertension prevalence than those in maximum security units (Table 1), nearly one-third may experience this higher burden of cardiovascular disease and cost.

Because we used previously collected data, this analysis assumed the following: (1) hypertension diagnoses persist over a lifetime; and (2) individuals in prison and the community experience the same control and cardiovascular effects of hypertension. These assumptions are reasonable based on the epidemiology of hypertension and likely conservative (we do not, for example, account for the larger effect sizes for hypertension on cardiovascular outcomes for African Americans, a population over-represented in prisons). We focused on hypertension-related cardiovascular disease and did not consider other possible conditions caused or worsened by solitary confinement, suggesting this analysis underestimates solitary confinement's overall impact on health and related costs. While a wealth of research describes the impact of isolation on stress hormone dysfunction and adverse cardiovascular outcomes including hypertension and mortality, ${ }^{3}$ use of secondary data limited our ability to assess whether additional factors contributed to the increased hypertension prevalence among those housed in solitary confinement. 
Table 1 Calculation of the 31\% Difference in Hypertension from the 2015 Hawkley Report. Values from the 2015 Hawkley Report $^{3}$

\begin{tabular}{|c|c|c|c|c|}
\hline Age & $\begin{array}{l}\text { Individuals in solitary } \\
\text { confinement with } \\
\text { hypertension }\end{array}$ & $\begin{array}{l}\text { Total individuals in } \\
\text { solitary confinement }\end{array}$ & $\begin{array}{l}\text { Individuals living in } \\
\text { the general prison } \\
\text { population* with } \\
\text { hypertension }\end{array}$ & $\begin{array}{c}\text { Total } \\
\text { Individuals } \\
\text { living in the } \\
\text { general prison* }\end{array}$ \\
\hline $27-35$ & 35 & 56 & 36 & 206 \\
\hline $36-45$ & 108 & 245 & 24 & 157 \\
\hline Total (27-45) & 143 & 301 & 60 & 363 \\
\hline
\end{tabular}

\begin{tabular}{|c|c|}
$\begin{array}{c}\text { Hypertension rates among individuals in } \\
\text { solitary confinement }\end{array}$ & $\begin{array}{c}\text { Hypertension rates among individuals living in the } \\
\text { general prison population }\end{array}$ \\
$=\frac{143}{301}=47.51 \%$ & $=\frac{60}{363}=16.53 \%$ \\
& $\frac{\text { Hypertensive individuals in general prison population }}{\text { Total individuals in general prison population }}$ \\
\hline Difference in solitary confinement and general prison population hypertension rate: \\
$47.51 \%-16.53 \%=31 \%$
\end{tabular}

*In the maximum security wing of the same prison

\section{DISCUSSION}

This study projects the lifetime cardiovascular disease and cost burden associated with the increased prevalence of hypertension diagnoses found in persons in solitary confinement compared with maximum security housing in the same prison. In 2017 , over 60,000 US individuals were held in solitary confinement for 15 days or longer. ${ }^{5}$ Applying our findings to just the 25,000 individuals held in "supermax" solitary confinement units ${ }^{6}$ would alone result in $\$ 155$ million in additional future healthcare costs and a loss of 5673 QALYs (Fig. 1)-likely significant underestimates given the widespread use of solitary confinement outside of "supermax" units. These findings, coupled with the growing consensus that solitary confinement is counter-productive as a public safety measure, ${ }^{5,6}$ suggest an urgent need to dramatically 
NUMBERS ABOUT THE APP

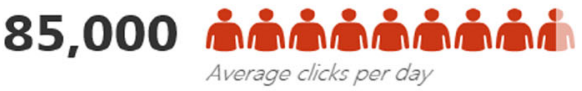

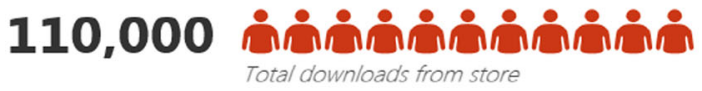 \\ 65,000 ำกำกำกำกำก \\ Number of revisits within a month
}

\title{
$\$ 155,000,000$ in
}

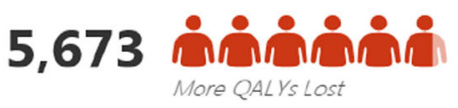

78

More Myocardial Infarctions

\section{3}

Figure 1 Increased adverse cardiovascular outcomes and high associated costs. For the $\mathbf{2 5 , 0 0 0}$ people currently in solitary confinement in US supermax prisons, a $31 \%$ increase in prevalence of hypertension will result in the following additional outcomes over the next 45 years (assuming an average life expectancy of 80 years old and the development of premature hypertension at age 35), compared with their counterparts in the maximum security wing of the same prison who experience less social isolation. 
reduce solitary confinement using alternative strategies that achieve safety without compromising health. This study also suggests cardiovascular disease organizations could join other associations in calling for solitary confinement reform and for the study of environmental health risks experienced by people in prison, including those in solitary confinement.

Corresponding Author: Brie A. Williams, MD, MS; Department of Medicine, Division of GeriatricsUniversity of California, San Francisco, San Francisco, USA (e-mail: brie.williams@ucsf.edu).

Authors' Contributions All those listed as authors had an active role and significant impact on conceptualizing, performing, analyzing, and/or writing up this research. No others made meaningful contributions to this work.

Funding Funding and support was provided by the Jacob \& Valeria Langeloth Foundation and the Medical Student Training in Aging Research (MSTAR) Program (NIH T35 AG026736).

\section{Compliance with Ethical Standards:}

Conflict of Interest: Dr. Williams has served as an expert witness and as a court consultant in legal cases related to prison conditions of confinement. These relationships have included the National American Civil Liberties Union; Squire Patton Boggs; the Center for Constitutional Rights; and others. Dr. Williams was an informal consultant on a different aspect of the case described in this study and did not testify about it in court. No organization played a role in the decision to write this manuscript or in the analysis described in this manuscript. No other authors have conflicts of interest to report.

Disclaimer: Sponsors played no role in the design and conduct of this study or in preparation, review, or approval of the manuscript.
Publisher's Note: Springer Nature remains neutral with regard to jurisdictional claims in published maps and institutional affiliations.

\section{REFERENCES}

1. American Medical Association House of Delegates. Reducing the Use of Restrictive Housing in Prisoners with Mental Illness: Resolution 412. 2018, page 641. https://www.ama-assn.org/sites/ama-assn.org/files/corp/media-browser/public/hod/a18-reference-committee-reports.pdf. Last accessed March 18, 2019.

2. Ahalt C, Haney C, Rios S, Fox MP, Farabee D, Williams B. Reducing the use and impact of solitary confinement in corrections. Int $J$ Prison Health 2017. 13(1):41-48. doi:https://doi.org/10.1108/IJPH-08-2016-0040

3. Expert Report of Louise C. Hawkley, Judge: Honorable Claudia Wilken. United States District Court Northern District of California Oakland Division: Todd Ashker, et Al., Plaintiffs, v. Governor of the State of California, et Al., Defendants.; 2015. https://ccrjustice.org/sites/default/files/attach/ 2015/07/Hawkley Expert Report.pdf. Last accessed March 18, 2019.

4. Odden MC, Pletcher MJ, Coxson PG, et al. Cost-effectiveness and population impact of statins for primary prevention in adults aged 75 years or older in the United States. Ann Intern Med 2015. 162(8):533-41. doi:https://doi.org/10.7326/M14-1430

5. Resnik, Judith and VanCleave, Anna and Bell, Kristen and Harrington, Alexandra and Conyers, Gregory and McCarthy, Catherine and Tumas, Jenny and Wang, Annie, Reforming Restrictive Housing: The 2018 ASCALiman Nationwide Survey of Time-in-Cell (October 10, 2018). Yale Law School, Public Law Research Paper No. 656. Available at SSRN: https:// ssrn.com/abstract=3264350or https://doi.org/10.2139/ssrn.3264350. Last accessed March 18, 2019.

6. 2014 ACLU Foundation. ACLU Briefing Paper: The Dangerous Overuse of Solitary Confinement in the United States. New York; 2014. https://www. aclu.org/report/dangerous-overuse-solitary-confinement-united-states. Last accessed March 18, 2019.

Publisher's Note Springer Nature remains neutral with regard to jurisdictional claims in published maps and institutional affiliations. 